\title{
Liderlik Tarzlarının Çalışanların Örgütsel Vatandaşlık Davranışına Etkisinde Bilgi Paylaşımının Rolü: Akademisyenler Örneği \\ (The Role of Knowledge Sharing in the Effect of Leadership Styles On Employee's Organizational Citizenship Attitudes: A Case of Academics)
}

\author{
Pouya TAHERi iD a Necmiye Tülin İRGE ${ }^{\text {D }}$ b \\ a İstanbul Aydın Üniversitesi, Lisansüstü Eğitim Enstitüsü, İstanbul, Türkiye. ptaheri90@yahoo.com \\ b İstanbul Aydın Üniversitesi, İ.İ.B.F. İşletme Bölümü, İstanbul, Türkiye, necmiyeirge@aydin.edu.tr
}

\begin{tabular}{|c|c|}
\hline MAKALE BİLGİSI & ÖZET \\
\hline $\begin{array}{l}\text { Anahtar Kelimeler: } \\
\text { Liderlik Tarzları } \\
\text { Örgütsel Vatandaşlık }\end{array}$ & $\begin{array}{l}\text { Amaç - Bu araştırmanın amacı, İstanbul'daki vakıf ve devlet üniversitelerinde eğitim veren } 755 \\
\text { akademisyene yönelik olarak, liderlik tarzlarının çalışanların örgütsel vatandaşlıklarına etkisinde bilgi } \\
\text { paylaşımının aracılık rolünün yapısal eşitlik modeli yardımıyla belirlenmesidir. }\end{array}$ \\
\hline Bilgi Paylaşımı & $\begin{array}{l}\text { Yöntem - Bu çalışmada, bağımlı değişken olarak örgütsel vatandaşlık, bağımsız değişken olarak liderlik } \\
\text { tarzları ve aracı değişken olarak bilgi paylaşımı ele alınmıştır. Araştırma ilişkisel tarama modelidir. }\end{array}$ \\
\hline $\begin{array}{l}\text { Gönderilme Tarihi } 5 \text { Eylül } \\
2021 \\
\text { Revizyon Tarihi } 1 \text { Aralık } \\
2021 \\
\text { Kabul Tarihi } 10 \text { Aralık } 2021\end{array}$ & $\begin{array}{l}\text { Anakütle İstanbul'daki vakıf ve devlet üniversitesinde görev yapan akademisyenler, örneklem ise } \\
\text { araştırmaya gönüllü katılan } 755 \text { akademisyendir. Kullanılan ölçekler beşli likert yapısında, Türkçe } \\
\text { geçerlik ve güvenirlik çalışması yapılmış olan örgütsel vatandaşlık davranışı, liderlik tarzları ve bilgi } \\
\text { paylaşımı ölçekleridir. İlk aşamada, Açıklayıcı Faktör Analizi (AFA) sonucunda, faktörler başarılı bir } \\
\text { şekilde indirgenmiştir. Diğer aşamada, yapı geçerliliği için Doğrulayıcı Faktör Analizi (DFA) kullanılarak, } \\
\text { uyum iyiliği sonuçları uygunluk göstererek son aşamada belirlenen modele yönelik ilişkilerin } \\
\text { belirlenmesi amaçlı Yapısal Eşitlik Modeli (YEM) tahmin edilmiştir. }\end{array}$ \\
\hline \multirow[t]{2}{*}{$\begin{array}{l}\text { Makale Kategorisi: } \\
\text { Araştırma Makalesi }\end{array}$} & $\begin{array}{l}\text { Bulgular - YEM sonucunda, liderlik tarzları bilgi paylaşımı üzerinde artırıcı yönde etkili ve bilgi } \\
\text { paylaşımı ise, örgütsel vatandaşlı üzerinde artırıcı yönde anlamlı etkili çıkmıştır. Bilgi paylaşımının } \\
\text { liderlik tarzı ile örgütsel vatandaşlık davranışı arasındaki aracılık görevinin anlamlılığını incelemek } \\
\text { amacıyla, bootstrap analizinden yararlanılmıstır. Bootstrap standardize edilmiş değer aralıklarının sıfır } \\
\text { olmadığı ve anlamlı olduğu görülmüştür. Bu durum, bilgi paylaşımının liderlik tarzı ile örgütsel } \\
\text { vatandaşlık davranışı ilişkisinde aracılık rolünün olduğunu göstermiştir. }\end{array}$ \\
\hline & $\begin{array}{l}\text { Tartışma - Liderler, çalışanlarının davranış ve tutumlarına yön verme hususunda ciddi bir etkiye sahiptir. } \\
\text { Liderlerin çalş̧anlara ait olan bilgilerin akışı ve paylaşımını gerçekleştirebilecek bir örgüt kültürü } \\
\text { oluşturulması ve söz konusu bilgilerin örgütsel karar verme süreçleriyle bütünleşmesi sayesinde, bu } \\
\text { döngü içinde örgütsel vatandaşlı davranışlarının gelişimi noktasında da önemli bir görevi } \\
\text { bulunmaktadır. Bu çalışmada, liderlik tarzları örgütsel vatandaşlık davranışını ve bilgi paylaşımını pozitif } \\
\text { yönde etkilemektedir ve bilgi paylaşımı aracı role sahiptir. Alanyazında bu değişkenlere yönelik aracılık } \\
\text { etkisi araştıran kısıtlı sayıda çalışma bulunmaktadır. Farklı sektörler ve farklı örneklem için çalışma } \\
\text { genişletilebilir. }\end{array}$ \\
\hline
\end{tabular}

\section{ARTICLE INFO}

Keywords:

Leadership Style

Organizational Citizenship

Knowledge Sharing

Received 5 September 2021

Revised 1 December 2021

Accepted 10 December 2021

Article Classification:

\section{ABSTRACT}

Purpose - The purpose of this research is to determine the mediating role of knowledge sharing in the effect of leadership styles on organizational citizenship of employees with the help of structural equation model for 755 academicians who teach at foundation and state universities in Istanbul.

Design/methodology/approach - In this study, organizational citizenship as a dependent variable, leadership styles as an independent variable, and knowledge sharing as a mediating variable are discussed. The research is a relational screening model. The population is academics working at foundation and state universities in Istanbul, and the sample is 755 academics who voluntarily participated in the research. The scales used are organizational citizenship behavior, leadership styles, and knowledge sharing scales, in a five-point likert structure, for which Turkish validity and reliability studies were conducted. In the first stage, factors were successfully reduced as a result of Explanatory Factor Analysis (EFA). The other stage, by using Confirmatory Factor Analysis (CFA) for construct validity, the Structural Equation Model (SEM) was estimated in order to determine the relationships for the model determined in the last stage by showing goodness of fit results. 

sharing and knowledge sharing was found to be significantly effective on organizational citizenship. Bootstrap analysis was used to examine the significance of the mediation role of knowledge sharing between leadership style and organizational citizenship behavior. Bootstrap standardized value ranges were found to be non-zero and significant. This showed that knowledge sharing has a mediating role in the relationship between leadership style and organizational citizenship behavior.

Discussion - Leaders have a serious impact on directing the behavior and attitudes of their employees. Leaders have an important role in the development of organizational citizenship behaviors in this cycle, thanks to the creation of an organizational culture that can realize the flow and sharing of information belonging to employees and the integration of said information with organizational decision-making processes. $\mathrm{n}$ this study, leadership styles positively affect organizational citizenship and knowledge sharing, and knowledge sharing has a mediating role. There are a limited number of studies in the literature investigating the mediation effect on these variables. The study can be extended for different sectors and different samples.

\section{GíRiş}

Günümüz işletmelerinin varlıklarının devamlılıkları açısından, iş tanımlarında yer alan biçimsel olarak belirtilmiş rollerinden başka davranışta bulunan ve örgütlerine izafi yönden ciddi boyutta rekabet avantajı kazandıran lider yöneticilere duydukları gereksinimde artış bulunmaktadır (Shafique vd., 2019:115). Liderler sahip oldukları değer ve vizyonlarla şirketin örgütsel yapısına yön vererek çalışanlarına yol gösterici ve rol model olurlar. Liderlerin göstermiş oldukları davranışlar; mevcut güçlerinin kullanımları, alınmış olan kararlar, şirket ve şirket çalışanları üzerinde etkili olmaktadır (Bavik vd., 2018:324). Özellikle, liderler çalışanlarının davranış ve tutumlarına yön verme hususunda ciddi bir etkiye sahiptir. Bununla birlikte, liderlerin çalışanlara ait olan bilgilerin akışı ve paylaşımını gerçekleştirebilecek bir örgüt kültürü oluşturulması ve söz konusu bilgilerin örgütsel karar verme süreçleriyle bütünleşmesi noktasında da önemli bir görevi bulunmaktadır (Bello, 2012:230).

Çalışanların arasındaki bilgi paylaşımlarının yetersiz seviyelerde kalması, kişilerarası ilişki ve güveni ortadan kaldırmakta, çalışanların yaratıcılık ve öğrenme sürecini ilerletme politikasını bozabilmektedir (Connelly vd., 2012:65). İşletmelerin rekabet avantajı elde etmesi, zaman geçtikçe örgütsel öğrenmeye daha fazla bağlı bir duruma gelmektedir. Bu kapsamda, çalışanların yeni bilgiler öğrenmesi, öğrendikleri veya sahip oldukları bilgileri örgütsel bazda paylaşmaları, örgütsel öğrenmeyi ve buna bağlı olarak da işletmeninin rekabet avantajı sağlamasına yardımcı olmaktadır (Gagne, 2009:571).

Bilgi yönetiminin ana hedeflerinden biri, örgütün bilgi potansiyelinden en üst düzeyde yararlanmak ve üyelerin birbirlerinin bilgilerini kullanma yoluyla sinerji etkisinden faydalanıp daha çok bilginin üretilebilmesine katkıda bulunmaktır (Öztekin vd., 2015:5). Bilgi paylaşımı, bu sürecin kilit noktalarından birini teşkil etmektedir. Çünkü, örgütlerin en önemli varlığı olarak görülen bilginin değeri; paylaşılması, transfer edilmesi, dağıtılması ve tüm üyeler tarafından içselleştirilmesiyle oluşmaktadır (Schutte ve Barkhuizen, 2015:134). Yöneticisinin kendisiyle bilgi paylaşımında bulunduğunu gören çalışanın, bu duruma bağlı olarak hissedeceği örgütsel desteğin artacağı ve örgütün onu arka plana atma gibi bir niyetinin olmadığını düşüneceği kabul edilmektedir. Bunun sonucunda bireyler, başka örgüt çalışanlarıyla bilgi paylaşımında bulunmaktan çekinmeyerek, bilgi paylaşımlarının çoğalacağı varsayılmaktadır. Bu döngü içinde, çalışanların örgütsel vatandaşlık davranışları gelişecek, olumlu performans gelişimi ve çalışanlar arasında iş birliği artarak, örgütsel hedeflere katkı sağlayacaktır (Suppiah ve Sandhu, 2011:466).

Buradan hareketle, modern liderlik tarzlarına uygun olarak liderlik yapacak kişilerin, çalışanların örgütsel vatandaşlık davranışlarını ortaya çıkarması ve bu süreçte de bilgi paylaşımının aracı rolünün olup olmadığının belirlemesi, araştırmanın motivasyonunu oluşturmuştur. Çalışmanın amacı, İstanbul' da bulunan vakıf ve devlet üniversitelerinde eğitim veren 755 akademisyene yönelik olarak, liderlik tarzlarının çalışanların örgütsel vatandaşlıklarına etkisinde bilgi paylaşımının aracılık rolünün yapısal eşitlik modeli yardımıyla belirlenmesidir.

\section{KAVRAMSAL ÇERÇEVE}

\subsection{Liderlik ve Liderliğin Önemi}

Liderlik olgusu, insanların toplu bir biçimde yaşamaları ile başlamaktadır. Genel olarak, liderlik yapılacak bir göreve yönelik olarak ihtiyaçların belirlenmesi ve görevin ne şekilde yapılacağının anlaşılabilmesi adına 


\section{P. Tahari - N. T. İrge 13/4 (2021) 3652-3667}

beraberindeki diğer kişileri etkilemesi süreci ve ayrıca hedeflenen veya paylaşılan amaçları gerçekleştirebilmeye yönelik bireysel ve kollektif gayretlerin tamamı şeklinde tanımlanabilir (Van Wart, 2013:556). Werner (1993)'e göre liderlik, belli bir zaman aralığında, belli bir durumda ve belirli şartlar altında bir grupta bulunan üyelerin örgütsel amaçlarını gerçekleştirebilmeleri için çaba göstermelerini teşvik eden, ortak hedeflere varmaları konusunda destek olan, tecrübelerini aktaran ve uygulanan liderlik yönteminden memnun kalmalarını sağlayan bir etkileme sürecidir. Hodgetts (1999)'ın görüşüne göre, liderlik belirlenmiş olan amaçlara ulaşma noktasında insanların sarf ettikleri çabalara yön verme ve etki etme süreci şeklinde ifade edilmektedir. Cooper (2003)'in ifadesiyle liderlik, temel olarak belirlenmiş bir amacı gerçekleştirmek adına gruptaki üyelerin çabalarını motive etme, planlama ve kontrol altında tutma görevidir. George ve Jones (2008) liderlik kavramını, gruptaki üyelerden herhangi birinin örgütsel hedeflere varmak adına başka grup üyelerine etki etmesi şeklinde açıklamaktadırlar. Yukl (2010)'ın tanımına göre, liderlik gruptaki üyelerden birinin gruptaki eylemleri örgütsel hedeflere ulaşılabilmesi için yönlendirmesi veya koordine etmesidir.

Liderlik tarzları zaman içinde gelişmiş ve farklı tanımlar literatürde yerini almıştır. Bir çok liderlik tarzı içinden araştırmalarda en çok ele alınan liderlik tarzları genel olarak şöyle açıklanabilir:

Demokratik Liderlik: Demokratik bir lider, astlarından fikir alarak onların karar verme, planlama ve örgütlenme eylemlerine katılımlarına destekte bulunur. Bir başka deyişle, demokratik lider astlarını karar alma aşamalarının bir parçası olmaları hususunda destekler. Çalışanlarını gerçekleştirdikleri işlere etki eden durumlar konusunda bilgilendirir, fikir ve görüşlerini açıklayarak tavsiyelerde bulunmalarına izin verir (Bello, 2012:231; Morçin ve Morçin, 2013:74; Bhargawi ve Yaseen, 2016:90; Altıntaş, 2019:67).

Otokratik Liderlik: Bu tarz liderlik, bürokratik toplumlarda yetişerek böyle bir eğitimi almış olan ve belli bir birikimi bulunan insanlar açısından uygun bir liderlik türüdür. Otokratik lider yönteminde, yetkinin merkezde toplanmış olması nedeniyle karar alma süreci oldukça hızlıdır. Bir başka deyişle, otokratik liderler sorumluluk ve otoritelerini devretmeden tüm kararları kendileri alırlar, ancak astlarının karar verme süreçlerine dahil olmalarına izin vermezler (Wnag vd., 2011:226; Saleem, 2015:566; Sougui vd., 2015:6; Shafique vd., 2019:116).

Tam Serbesti Tanıyan Liderlik: Tam serbesti tanıan liderler, astların kendilerine ait hedefleri yine kendilerinin belirlemesini sağlar. Çalışanların, planlarını ve programlarını yapmalarına imkan veren ve astların kendilerine ait kararları kendilerinin belirlemesini sağlayan bir yaklaşım içindedir. Mesleki uzmanlık durumlarında ve bilim insanlarının çalışmalarında, şirketlerin Ar-Ge departmanlarında görev alan yüksek bilgi, deneyim ve uzmanlığa sahip çalışanların yenilikçi ve yaratıcı fikirler geliştirmelerinde bu tarz bir liderlik ön plana çıkmaktadır (Sougui vd., 2015:6; Bhargawi ve Yaseen, 2016:91 Altıntaş, 2019:69).

Destekleyici Liderlik: Destekleyici liderlik anlayışında; liderin tavırları dostça, sempatik ve astlarının gereksinimlerini karşılamak adına bir davranış olarak benimsenmektedir. Bu tarz liderler, grup üyeleriyle birlikte karar almazlar, ancak onların fikir ve tavsiyelerindan faydalanarak karar alırlar. Ödül ve katılım sistemlerini uygularlar. Aşağıdan yukarıya, yukarıdan aşağıya olacak şekilde çift taraflı bilgi akışında bulunurlar. Örgüte yönelik hedefler, örgüt üyelerine danışılması sonrasında tespit edilerek oluşturulan emirler ile örgüt üyelerine iletilir (Zel, 2011:34; Aydoğdu, 2013:69; Bhargawi ve Yaseen, 2016: 89).

Vizyoner Liderlik: Vizyoner liderlik yaklaşımındaki liderler, etkili olabilmek adına belirsiz verileri başarılı bir biçimde tahlil edebilme ve çözümlemelerine imkan tanıyan düşünme yeteneğine sahip ve ortaya çıkan sorunların üstesinden gelerek fırsatlar yaratabilecek fikirler sunabilen kişilerdir. Ayrıca vizyoner liderlerin, tutarlılığı ön planda tutarak çevresindeki alternatif yöntemleri araştıran kişiler olması beklenmektedir (Cooper, 2003:71; Longe, 2014:71; John ve Chattopadhyay, 2015:3; Altıntaş, 2019:73 ).

Hümanist Liderlik: Hümanist liderlikte öne çıan en önemli özellik, liderin babacan (patrimonial) tavırlara sahip olması başka bir ifadeyle korumacı bir rol üstlenmesidir. Hümanist liderlikte, bazı zamanlar orta basamaktaki çalışanların fikirleri de alınır. Çalışanlarının motivasyonunu duygusal yönlendirmeler ile sağlar. Liderin çalışanları üzerinde uyguladığı yöntem ödül sistemi olmakla beraber mecburi bir durum bulunmadıkça cezalandırma yolunu kullanmaz (John ve Chattopadhyay, 2015:3; Jyoti ve Bhau, 2015:5; Kuruşçu ve Aydoğan, 2018: 170).

Dönüşümcü Liderlik: Dönüşümcü liderlik, örgütte yaşanan etkili ve ani değişimleri iyileştirme üzerine olan bir liderlik türüdür. Değişimi etkin bir biçimde başlatma, değişime yol gösterecek ileri görüşlülük meydana 


\section{P. Tahari - N. T. İrge 13/4 (2021) 3652-3667}

getirme ve değişime yönelik gereksinimleri belirlemede lidere olanak verecek kabiliyetlerin toplamıdır. Dönüşümcü liderler, çalışanların gözünde güvenilir kişilerdir ve örgüte yönelik olarak tanımlanabilir bir vizyon tespitinde bulunan konumdadır (Longe,2014:71; Jyoti ve Bhau, 2015:7; Mertel vd., 2020:3076).

Etkileşimci Liderlik: Bu tarz liderler, astlarının gereksinimlerini ön planda tutarak astları öncesinde belirlenmiş olan performans düzeyine vardığında, yeni gereksinimleri karşılamaya çabalamaktadır. Etkileşimci liderlikte, liderler astlarına ödüller verdiği ve bunun karşıllğında da astlarından çaba ve performanslarını aldığı bir değiş-tokuş süreci bulunmaktadır. Bir başka ifadeyle, etkileşimci liderlik, yöneticilerin astlarını net ve açık bir biçimde önceden belirlenen görev tanımlamalarıyla motive ettiği ve astlarının hedeflere varmadaki çabalarına yönelik olarak ödüllendirme sistemini kullandığı bir yaklaşımdır (Yukl, 2010:58; Masa'deh vd., 2016:685; Mo ve Shi, 2017:155).

\subsection{Bilgi Paylaşımı}

Bilgi, rekabetçi ve dinamik bir ekonomide sürdürülebilir bir rekabet üstünlüğü yaratan önemli bir organizasyonel kaynaktır (Wang ve Noe, 2010:115). Bilgi paylaşımı, yeni bilginin yaratılması ve inovasyonun temelini oluşturan fikirlerin, görüşlerin, gerçeklerin ve bilgilerin birleştirilmesiyle meydana gelmektedir (Camelo-Ordaz, vd., 2011:1444).

Bilgi paylaşımı, bilgi aktarımı ve bilgi alışverişinden farklıdır. Bilgi aktarımı, hem bilgi kaynağı tarafından bilginin paylaşılmasını hem de alıcının bilgiyi edinmesini ve uygulamasını içermektedir. Bilgi aktarımı, bilginin farklı birimler, bölümler veya organizasyonlar arasındaki hareketini tanımlamak için kullanılmaktadır. Bilgi paylaşımı, şirkette bulunan çalışanların gereksinimi olan bilgiye basit ve hızlı bir şekilde ulaşabilmelerine yönelik uygulama, sistem ve süreçlerin tamamını içine alan izafi olarak karışık bir kavram olmakla beraber; esas olarak kişilerin birbiri ile etkileşimlerinden doğan, akıcı bir iletişim, diyalog ve tartışmalar yardımıyla kişisel düzeyde sahip olunan bilginin örgütsel bazdaki dağılımını belirtmektedir (Keskin vd., 2018:94).

Bilgi paylaşımı bilgi yönetiminin bir unsurudur. Bilgi paylaşımı, işgörenlerin sahip oldukları enformasyon, fikir, öneriler ve uzmanlıklarını başkalarına aktarmasıdır (Kianto vd., 2017:13). Bilgi paylaşımına yönelik yönetim desteğinin, çalışanların bilgi paylaşım kültürü (çalışanların güveni, başkalarına yardım etmek için uzmanların istekliliği) ve bilgi paylaşma istekleriyle ilgili algıları ile pozitif ilişkili olduğu belirlenmiştir. Lee vd. (2006), üst yönetim desteğinin, çalışanların bilgi yönetimine olan bağl1lı̆̆ını etkileyerek, hem bilgi paylaşım seviyesini hem de kalitesini etkilediğini ortaya koymuştur.

Bilgi yönetiminde başarı, şirketin açık bilgiden ve kişilere ait olan örtülü bilgiden yeni bilgiler üretebilme ve üretilen bilgileri aktarabilme kapasitesi ile doğrudan ilişkilidir (Heisig vd., 2016:1172). Bir işletme, açık ve örtük bilgiler arasında oluşan etkileşimler neticesinde bilgi ortaya çıkarmaktadır. Söz konusu iki çeşit bilginin aralarındaki etkileşimi, Nonaka ve Takeuchi (1995) "bilgi dönüşümü" şeklinde adlandırmaktadır. Teorisyenlerin düşüncelerine göre, işletmedeki açık ile örtük bilgi arasındaki etkileşimlerin belirlenmesi ve örtük bilgiyi açık bilgiye çeviren aşamaların amaçlı olacak şekilde planlanması yolu ile şirket içerisinde yeni bilgiler meydana getirilmektedir. Bu bakımdan dönüşüm sürecinde örtük ve açık bilgi gerek nitelik gerek de nicelik yönünden gelişim göstermektedir.

Örgütsel bilgi, kişisel bilgilerin toplamının yanında, başka organizasyonların kolayca taklit edemeyeceği biçimde insan, yönetim ve teknoloji öğeleri arasında meydana gelen bilgi kaynaklarını belirtmektedir. Bu bilgileri başka kurumların taklit etmesi zordur zira söz konusu üçöğe arasında ortaya çıkan etkileşim, örgütün sahip olduğu tarihi ve kültürü yansıtmaktadır (Hsu ve Sabherwal, 2012:491). Örgütsel bilgi genellikle bireysel, grup ve örgütsel düzeylerde sahip olunan deneyimlerin, değerlerin, enformasyonun ve uzmanlık görüşlerinin dinamik bir harmanıdır. Çalışanların zihinlerinde bireysel olarak oluşur ve diğer çalışanlar ve çevreyle etkileşimleri sonucunda ortaya çıkar. Bireysel bilgi diğerleri ile paylaşılmadığı sürece, örgütsel bilgiye dönüşmeyecektir (York-Barr ve Duke, 2004:258).

Açık bilgi, kurallar ve prosedürlerde biçimlendirilen ve belirlenebilen kavramlar, bilgiler ve içgörüler anlamına gelmektedir. Bu bilgilerin erişimi, depolanması ve aktarılması, kurumsal belgeler ve veritabanları gibi bilgi sistemleri ile sağlanmaktadır. Dyer ve Singh (1998)'e göre, açık bilgi sadece bilgi olabilmektedir. Cohen (1998) için bilgi, bağlamsal bir bilgidir ve açık, biçimsel bir bilgi biçimi olarak ele alınmaktadır. Açık 


\section{P. Tahari - N. T. İrge 13/4 (2021) 3652-3667}

bilgi örnekleri arasında, yazılım geliştirme veya ürün üretimi için ayrıntılı mühendislik özellikleri bulunmaktadir.

Örtülü bilgi, bireylerde veya örgütsel bağlamda "gömülü" olan daha az tanımlanabilir içgörü ve becerileri ifade etmekte olup tecrübe ile ilişkilidir. Çalışanlar örgütsel uyum ve öğrenmeyi başarmak için toplu olarak alışkanlıkları geliştirmektedir. Vizyon oluşturmak, hedef belirlemek, değer ve inançları yönlendirmek ve karar vermek idealist bilgiyi ortaya çıkarmaktadır (Loebbecke vd., 2016:7). Bu bilgi, çalışanların yapmış oldukları okuma, fiil ve birbirleri ile tartışmaları sonucu oluşmaktadır (Lee vd., 2016:4).

\section{3. Örgütsel Vatandaşlık Davranışı}

Örgütsel vatandaşlık davranışı, örgütsel yapılanmaya yarar sağlayan fakat herhangi bir emre bağlı olmayan yani ast-üst ilişkisi göstermeyen davranışlar ve tutumlar içermektedir. Örgütsel vatandaşlık davranışı; çalışanların işlerindeki görevlerinin ötesinde gösterdikleri kolaylaştırıcı gayretler ve yardım etme davranışlarını içermektedir (Wang vd., 2011:119). Literatürde, Podsakoff vd. (2000), Sun vd., (2007), Tanaka (2013) ve Tambe ve Shanker (2014) çalışmalarında; örgütsel vatandaşlık davranışı, herhangi bir çıkar gözetmeden, örgütün faydasına olabilecek her biçim özverili davranışı, mesleğini yapma tutkusuyla çalışanın gösterebilmesi olarak açıklanmaktadır. Örgütsel vatandaşlık davranışı farklı boyutlardan oluşan bir kavramdır. Örgütsel vatandaşlık davranışı; özgecilik, vicdanlılık, centilmenlik, nezaket ve sivil erdem olmak üzere beş boyut üzerinden ele alınmaktadır.

Özgecilik: Örgütsel vatandaşlığın bu boyutu, literatürde çeşitli adlar ile yer almaktadır. Bunlar; başkalarını düşünme, fedakarlık ve alturizmdir. Çalışmalarda "olumlu sosyal davranış göstermek”, "yardım etme davranışı" ve "özgecilik" terimlerinin genellikle birbirinin yerine kullanıldı̆̆ı görülmektedir. Olumlu sosyal davranış; yardım davranışı ve özgeciliği içine alan, gönüllülük esasına dayalı, bireyin kendisinden başka kişilerin ruhsal ve fiziksel sağlıklarını pozitif olarak etki etmeye yönelik davranış biçimidir. Olumlu sosyal davranış en kapsamlı sınıftır. Bu davranış tarzına örnek olarak; dayanışma, hayırseverlik ve paylaşma verilebilir. İkinci kavram olarak sayılan yardım etme davranışıysa olumlu sosyal davranışlar türlerinden sadece biridir. Yardım etme davranışının da bir alt sınıfı özgeciliktir (Kağıtçıbaşı ve Cemalcılar, 2014:242). Bir iş görenin başka bir iş görene yardım etmesi, yapmakta zorlanacağı bir hususta başarılı elde edebilmesi amacıyla gönüllülük esasına dayalı olarak yardımda bulunmasıdır. Gönüllülük esasına dayalı bir biçimde gerçekleşen eylemlerin neticesinde, iş görenin başarımını yükseltmekte, iş görenler içinde iş birliği artmakta ve örgüt amaçlarına yönelik katkıda bulunulmaktadır (Demirel vd., 2011:37). Özgecilik düzeyindeki davranışlara örnek olarak; yeni bir iş görene iş gereçlerinden ne şekilde yararlanacağını öğretme, çalışma arkadaşının görev yükümlülüğünü rahatlatma, çalışma arkadaşının olmaması durumunda iş sürecinde yokluğunu hissettirmeme verilebilir.

Vicdanlılık: Vicdanlılık, çalışanların rolleriyle ilgili olması gerekenlerin ötesinde gösterdikleri davranışları kapsar. Başka bir deyişle, çalışanların çalışma yaşamlarındaki görevlerinin üstünde göstermiş oldukları gayretlerdir. Diğer yandan, çalışanların bu boyut çerçevesinde verimliliklerini arttırabilmek amacıyla zamanı düzenli bir şekilde kullanmak ve işletme adına çaba gösterdikleri söylenebilir (Altıntaş, 2019: 45). Üstün görev bilinci boyutu, işletmede işgörenlerin resmi rollerini kendilerinden istenenin ötesinde yerine getirmeleridir. İşgörenlerin kötü hava koşullarında da işe vaktinde gelmeye gayret göstermesi, mola sürelerini aşmaması, örgütte yapılan toplantılara düzenli ve vaktinde katılmalarıdır. Diğer yandan çalışanın; mesai bitmesine karşın, bitirmesi gereken iş daha bitmemişse ve işini bitirmek amacıyla çalışmayı sürdürmesi, vicdanlılık boyutuna örnektir. Sonuç itibariyle vicdanlılık, çalışanların kimsenin kendisini görmediği zamanda, kendi isteğiyle gösterilen davranıştır (Çetinkaya, 2014:246).

Centilmenlik: Örgütsel vatandaşlık davranışında başka bir boyut olan centilmenlik boyutu, çalışanların örgütte ortaya çıkan negatif durumlara karşı şikayette bulunma veya yakınma tarzı hareketlerden uzaklaşarak işletmenin aktivitelerine gönüllü bir şekilde katılmalarıdır. Centilmenlik boyutuna göre, sahip oldukları koşulları olduğu gibi benimseyip şirkette oluşan yenilik ve değişimleri bir zorlama olmaksızın kabul etme eğilimindedir (Naktiyok, 2019:1060). Centilmenlik; işletmede çalışanlar arasında sorun olabilecek her türlü olumsuzluğu görmeme, önemsiz sorunları büyütmeme veya şikayetçi olmadan sorunların oluşmasını engelleyen davranışlardır (Borman vd., 2001:56). Centilmenlik hareketi; oluşan sorunları büyütmeyen, olumlu tutumlarıyla çözüme odaklanan, işindeki durumunun negatif taraflarından ziyade, pozitif taraflarını gören, negatif ifadelerden kaçınan, hoş görü sahibi çalışanların davranışlarıdır. İşin sebep olduğu kaçınılmaz 


\section{P. Tahari - N. T. İrge 13/4 (2021) 3652-3667}

rahatsızlık ve zorlamalar karşısında hoş görülü olma, işlerde olumsuz bir durum meydana geldiğinde pozitif yaklaşımını koruma, öteki çalışanlar tarafından rahatsız edilmekten şikayet etmeme, diğer çalışanlar kendisi gibi düşünmediğinde sinirlenmeme ve onların düşüncelerine saygı duyma davranışlarıdır (Sun, vd., 2007:561).

Nezaket: Nezaket boyutunda bilhassa önceden bir problemin ortaya çıkacağı tahmin ediliyorsa böyle bir durumda alınacak karar ya da gerçekleşecek faaliyetler diğerlerine etki edecekse, etki altında kalacak bu bireylere konuyla ilgili bilgilendirme yapılmasını ifade etmektedir. Özetle, nezaket sahibi iş görenler hareketlerinin başkaları üzerindeki etkilerini göz önüne alırlar. Önceden haber verme, danışma hatırlatma ve bilgi alışverişi nezaket boyutuna örnek teşkil eder (Yorgancıoğlu vd., 2019:161). 1988 tarihinde ilk olarak Organ tarafından yazılan kitapta açıklanmış olup, "organizasyon içinde iş yükümlülükleri nedeniyle devamlı etkileşim içinde olmaları gereken ve birbirlerinin kararlarından, işlerinden etkilenen çalışanların gösterdiği pozitif davranışları belirttiği" ifade edilmektedir (Tambe ve Shanker, 2014:71). Organ bu davranış türünü açıklarken yararlandığı örnekler içinde; danışma, bilgi aktarımı, önceden haber verme, hatırlatma ve uygulanacak olanları özet şeklinde aktarma tarzı davranışlar yer almaktadır.

Sivil Erdem : Çalışanların, şirketin bir bütün şeklinde makro seviyede taahhüdünü ya da ilgisini ortaya çıkarması durumudur. Çalışanlar, yönetim sürecine etkin bir bir biçimde dahil olmakta (örnek olarak, örgütün hangi politikayı izlemesi gerektiği hususunda görüş bildirme, toplantılara katılma, politika tartışmalarına katılma); gönüllülükle katıldığını gösterme, fırsat ve tehditler için etrafını analiz etmekte (örnek olarak, örgüte etki edebilecek başka sektörlerdeki değişimleri takip etme) ve bireysel menfaatleri karşısında dahi olsa, işletme açısından en uygun olanı gerçekleştirmeye çabalamaktadır (örnek olarak, tehlike arz eden vaziyetleri ya da şüphe teşkil eden aktiviteleri bildirme, kapıları kilitleme). Bu tarz davranışlar, iş görenin sorumluluklarının farkında olan ve görev bilinci bulunan sivil erdem (civicvirtue) boyutunu belirtmektedir (Podsakoff vd., 2000:517). Sivil erdem, örgüt içinde etkin bir biçimde görev üstlenme ve sorumluluk alma durumudur. İşgörenin işletmenin gelişimini sağlayacak sorumluluklar üstlenmesidir. İşletmenin gelişmesine katkıda bulunması, bireyin kendi seçimine bırakılmıştır. İşgörenin işletmede meydana gelen problemleri analiz etmesi ve bunun neticesinde çözüm tavsiyeleri sunması, işletmenin hedeflerine uygun kararlarda destekte bulunması, değişimlere uyum sağlaması, işletmeden meydana gelen değişimleri izlemesi olarak belirtilmektedir (Tanaka, 2013:9).

\subsection{Liderlik Tarzları, Örgütsel Vatandaşlık ve Bilgi Paylaşımı İlişkisi}

Çalışanların kendilerine yönelik ilgi gösteren, destek davranışları sergileyen, kendilerini ödüllendiren, entellektüel uyarım sağlayan, katılımcı ve kendilerini cesaretlendirme yönünde algıladıkları liderlik davranışlarının, işi için zorunlu olan sorumlulukları yerine getirmenin yanı sıra, örgütün başarısı için gereken ve iş tanımı dışında kalan fazladan çabayı göstermek konusunda da çalışanları motive etmesi beklenmektedir. Çalışanlara ilgili davranan, her yönlü destek olduğunu belirten davranışlar sergileyen, yapılan olumlu her adımda ödüllendirme sistemi ile çalışanlarını motive eden, her türlü bilgi akışınında çalışanlarını dışlamayan ve olayların içinde tutmaya gayret gösteren liderlik tarzı sonucunda, çalışanlar örgüt içinde bir değerleri olduğunu, sahiplenildiklerini bilecek ve lidere-örgüte güven duyarak performanslarını yükselteceklerdir. Bu akış içinde, aynı zamanda örgüte bağlllık, örgüt kültürü gibi kavramların olumlu gelişmeleri yanısıra, örgütsel vatandaşlık davranışı çalışanlar arasında yaygınlık kazanacaktır. Bu durumda, çalışanların örgütsel vatandaşlık davranışı biçimlerinin gelişiminde yöneticilerin liderlik tarzları önemli bir öncül olarak karşımıza çıkmaktadır. Örgütsel vatandaşlık davranışı, çalışanların sorumlu oldukları iş tanımlarının ötesine geçerek, gönüllü biçimde istenilenlerden fazlasını yapmaya hazır olmalarıdır. Yöneticinin bilgileri paylaştığı, etkileşimci yaklaşımlar sergilediği, katılımcı ve destekleyici tarzda davrandığı çalışanlar, isteyerek gönüllü olarak, yönetici-çalışan ve çalışan-çalışan dayanışması içinde performanslarını arttırırlar. Çalışanlar arasında bilgi paylaşımının yeterli düzeyde olmaması, bireylerde güven ve ilişki dinamiklerini bozmakta, öğrenme sürecini ve yaratıcılığını geliştirme stratejilerini tehlikeye atabilmektedir. Liderler, çalışanların duygu ve düşüncelerini etkileyerek tutum ve davranışlara yön verirler, bunun en çarpıcı örneklerinden biri de örgütsel vatandaşlık davranışıdır. 


\section{P. Tahari - N. T. İrge 13/4 (2021) 3652-3667}

\section{YÖNTEM}

\subsection{Araştırma Modeli ve Hipotezler}

Araştırmanın ana hipotezi, liderlik tarzının örgütsel vatandaşlık davranışına yönelik etkisinde bilgi paylaşımının aracılık rolü üstlendiği yönüyledir. Araştırma modeli "ilişkisel tarama modeli"dir. İlişkisel tarama modelinde, değişkenlerin birlikte değişip değişmediği; değişme varsa bunun nasıl olduğu saptanmaya çalışılır. Çalışmada geliştirilen hipotezler şöyledir:

Hı: Liderlik tarzı ve örgütsel vatandaşlık davranışı arasında istatistiki olarak anlamlı ilişki vardir.

$\mathbf{H}_{2}$ : Liderlik tarzı ve bilgi paylaşımı arasında istatistiki olarak anlamlı ilişki vardır.

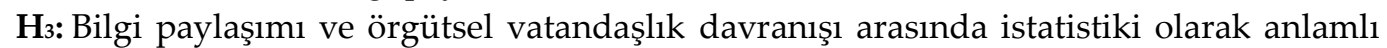
ilişki vardır.

H4: Liderlik tarzının örgütsel vatandaşlık davranışı üzerindeki etkisinde bilgi paylaşımı aracılık rolü üstlenmektedir.

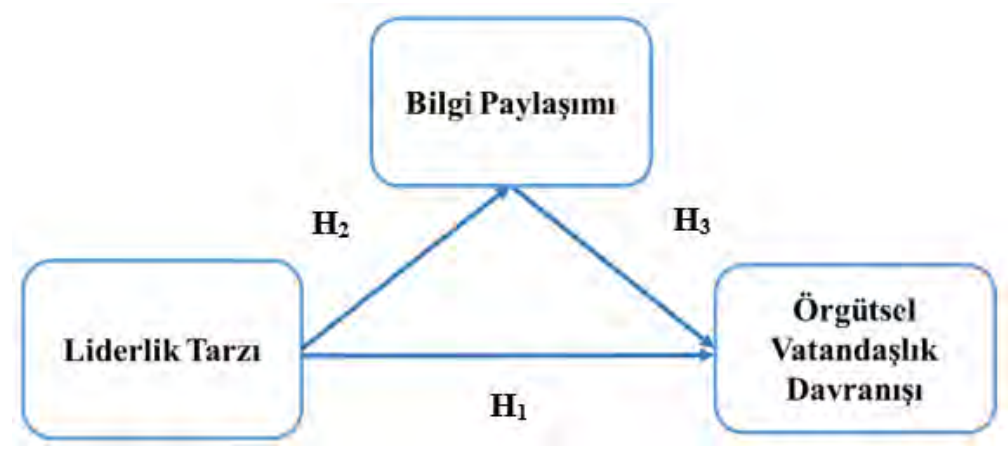

Şekil 1: Araştırma Modeli

\subsection{Araştırmanın Evren ve Örneklemi}

Çalışmanın evrenini, İstanbul'da faaliyette bulunan vakıf ve devlet üniversitelerinde görev yapan akademik kadro oluşturmaktadır. Yüksek Öğretim Kurumu (YÖK) akademisyen sayısı istatistikleri 2020'ye göre; İstanbul'da vakıf ve devlet üniversitesi toplam akademisyen sayısı ( araştırma görevlisi, öğretim görevlisi, doktor öğretim üyesi, doçent ve profesör) 36.896 kişiden oluşmaktadır. Örnekleme yöntemi olarak "basit tesadüfi örnekleme" uygulanmıştır. Anketlerin yapılabilmesi için İstanbul Aydın Üniversitesi Etik Kurulundan Anket Etik izni (20.02.2020) alınmıştır. Anketler, 25.02.2020 ve 30.05.2020 tarihleri arasında mail yolu ile uygulanmıştır. Veri giriş sürecinde kimi katılımcıların ankette yer alan soruların çoğunu yanıtlamamasından dolayı, geçersiz anketler analiz sürecine dahil edilmeyerek uygulamada toplam 755 anketten yararlanılmıştır. Önceden belirlenmiş olan ana kütleden seçilen örnek miktarı, Yazıcıoğlu ve Erdoğan (2004)'nın geliştirmiş olduğu tabloda 0.05 örnekleme hatası için $\mathrm{p}=0.50$ ve $\mathrm{q}=0.50$ için 381 kişi olacak şeklinde belirtilmiştir. Bu uygulamada, 755 örneklemle analizler yapılmıştır.

\subsection{Veri Toplama Arac1}

Anket uygulaması sonucunda oluşturulan verilere yönelik güvenilirlik testi olarak Cronbach Alpha, İkiye Bölme (split), Paralel, Mutlak Kesin Paralel (strict) testlerinden yararlanılmıştır. Cronbach Alpha testindeki değerin \%70 oranının üzerinde çıkması, anket uygulamasının başarılı sonuç verdiğini, kendi içinde tutarlılık gösterdiğini belirtmektedir (Sart, 2020:61). Bazı araştırmacılarsa testteki \%75 değerinin aşılmasını baz almaktadır (Sezgin \&Kınay, 2010:112; Sezgin, 2016:1286). Öteki değerlerin de \%70 oranının üzerinde çıması, ankette iç tutarlılı̆̆ın bulunduğunu ve elde edilen verilerin güvenilir olduğunu açıklamaktadır (Sart vd., 2018:120). Bu uygulamada gerçekleşen anketin güvenilirlik analiz neticeleri; Cronbach-Alpha $=0.913$, Paralel $=0.913$, Split $=0.881-0.886$ ve Strict $=0.910$ şeklinde ifade edilmektedir. Çalışmada, literatürde Türkçe geçerlik ve güvenirlik çalışmaları yapılmış, birçok araştırmacı tarafından kullanılmış ölçekler üzerinden analizler gerçekleştirilmiştir.

Bilgi Paylaşımı Ölçeği; Wang ve Wang (2012)'ın geliştirmiş olduğu ölçek 13 sorudan oluşmaktadır. Bu çalışmada kulanılan anket, Uçar (2018) “İşletmelerde çatışma yönetimi tarzları ile bilgi paylaşımı ilişkisi ve bir araştırma" isimli tez çalışmasından alınmıştır. Bu ölçekte açık bilgi paylaşımına yönelik 6 ifade (1-6.ci sorular), 


\section{P. Tahari - N. T. İrge 13/4 (2021) 3652-3667}

örtülü bilgi paylaşımı için 7 ifade (7-13.cü sorular) olmak üzere toplam 13 ifade yer almaktadır. Anket, 1=Kesinlikle Katılmıorum, 2=Katılmıorum, 3=Kararsızım, 4=Katıllyorum ve 5=Kesinlikle Katılmıyorum şeklinde 5'li Likert biçimindedir.

Liderlik Tarzı Ölçeği; Bass (1985) çalışmasında ilk hali oluşturulan daha sonra Bass ve Avolio (1993) çalışmasında revize edilen 36 sorudan oluşan çok faktörlü liderlik tarzı ölçeği kullanılmıştır. Bu çalışmada, Aydoğdu (2013) "An Empirical Study of The Relationship Between Leadership Styles and Organizational Commitment: The Mediating Role of Empowerment" konulu doktora tezinde kullandığı ölçek ele alınmıştır. Anket ilk olarak Yurtkoru (2001) tarafından Türkçeye çevrilmiş ve geçerlilik, güvenilirlik analizleri yapılmıştır. Çok faktörlü liderlik ölçeği, dönüşümcü ve etkileşimci liderlik olacak şekilde iki ana faktörden, 8 alt boyuttan oluşmaktadır. Dönüşümcü liderlik tarzı, idealleştirilmiş etki (1, 2,10,11,19,20,28,31 maddeler), ilham verici motivasyon $(3,12,24,34$. maddeler), entelektüel uyarım $(9,18,27,36$. maddeler), kişiselleştirilmiş görüş $(4,17,26$, 35. maddeler) alt faktörlerinden oluşmaktadır. Etkileşimci liderlik tarzı da koşullu ödül $(5,13,21,29$. maddeler), istisnaya göre yönetim (aktif yönetim tarz1 6, 14, 22, 30. maddeler ve pasif yönetim tarzı $7,15,23,32$. maddeler), laissez-faire $(8,16,25,33$. maddeler) alt boyutlarından oluşmaktadır.

Örgütsel Vatandaşlık Davranışı Ölçeği; Podsakoff vd. (1990)'nin geliştirdiği ve Ünüvar (2006) tarafından Türkçe geçerlik güvenirlik çalışması yapılan ölçektir. Bu çalışmada kullanılan anket, Aydın’ın (2015) “Liderlik Tarzları ile Örgütsel Vatandaşlık Davranışı Arasındaki İlişkide Örgüt Kültürünün Rolü: Bursa Serbest Bölgesinde Faaliyet Gösteren Firmalar Üzerinde Bir Araştırma" konulu tez çalışmasından alınmıştır. Toplam 24 madde içeren ölçek, "Diğerkamlık" (1, 10, 13, 15 ve 23'üncü maddeler), "Vicdanlılık" (3, 18, 21, 22 ve 24'üncü maddeler), "Centilmenlik" (2 (-), 4 (-), 7, 16 (-) ve 19 (-)'uncu maddeler), "Nezaketen Bilgilendirme" $(5,8,14,17$ ve 20'nci maddeler) ve "Sivil Erdem" (6, 9, 11 ve 12'nci maddeler) olmak üzere toplam beş boyutlu bir yapıdan oluşmaktadır.

\subsection{Verilerin Analizi}

Çalışmada kullanılan ölçekten elde edilen verilerin analizi IBM SPSS 24.0 ve AMOS 23.0 paket programı kullanılarak yapılmıştır. Birinci aşamada, anketin ilk bölümünü oluşturan demografik ve genel bilgilere ilişkin yüzde ve sıklık dağılımları sunulmaktadır. İkinci aşamada, çalışmada kullanılan ölçeklere yönelik açıklayıcı faktör analizi (AFA) uygulanmıştır. Ölçeğin yapı geçerliliği için ayrıca doğrulayıcı faktör analizi (DFA) uygulanmıştır. Son aşamada, ilişkilerin belirlenmesine ve hipotezlerin test edilmesine yönelik yapısal eşitlik modeli (YEM) uygulanmış ve sonuçlar değerlendirilmiştir.

\section{BULGULAR}

Katılımcıların \%65,4'ü kadın ve \%34,6'sı erkektir. Eğitim durumu açısından \%3,1'i ön lisans/lisans, \%25,8'i yüksek lisans ve $\% 71,0^{\prime}$ i doktora mezunudur. Medeni durum açısından $\% 42,9^{\prime}$ u bekar iken, $\% 57,1^{\prime} i$ evlidir. Katılımcıların \%55,6'sı vakıf sektörde, \%44,4'ü devlet sektöründe çalışmaktadır. Akademisyenlerin \%28,5'inin meslekteki çalışma süresi 1-5 yıl, \%20,1'inin 6-10 yıl, \%12,6'sının 11-15 yıl ve \%38,8'inin 15 yıl ve üzerindedir. Diğer yandan, akademisyenlerin \%55,4'ünün kurumda çalışma süresi 1-5 yıl, \%19,7'sinin 6-10 yıl, \%7,3'ünün 11-15 yıl ve \%17,6' sının 15 yıl ve üzerindedir. Katılımcıların \%2,1'inin çalıştığı kurumdaki çalışan sayısı 15 kişi ve altında, \%15,5'inin 16-100 kişi, \%12,8'inin 101-250 kişi ve \%69,5'inin 250 kişi ve üzerindedir.

Ölçeklere yönelik olarak açılayıcı faktör analizinin yapılması öncesinde, veri setinin faktör analizine uygunluğu test edilmiştir. Veri setinin, açıklayıcı faktör analizi yönünden uygun bulunduğunun yapılan testlerle onaylanması neticesinde, faktör yapısının ortaya konulması amacıyla faktör tutma yöntemi olarak varimax döndürme yaklaşımı ve temel bileşenler analizi metodundan faydalanılmıştır. 
P. Tahari - N. T. İrge 13/4 (2021) 3652-3667

Tablo 1: Faktör Analizi Sonuçları ve Cevap Ortalamaları

\begin{tabular}{|c|c|c|c|}
\hline Liderlik Tarzı Ölçeği & $\begin{array}{c}\text { Varyansı Açıklama } \\
\text { Yüzdesi }\end{array}$ & $\begin{array}{c}\text { Cronbach-Alpha } \\
\text { (CA) }\end{array}$ & Cevap Ortalaması \\
\hline Dönüşümcü Liderlik & $\% 39.54$ & 0.915 & 3.45 \\
\hline Etkileşimci Liderlik & $\% 32.21$ & 0.913 & 2.78 \\
\hline \multicolumn{4}{|c|}{$\mathrm{KMO}=0.932 ;$ Bartlett $\chi 2=6732.98$ ve $\mathrm{p}=0.000 ;$ Varyans Aç1klama Yüzde: $\% 71.75$} \\
\hline Örgütsel Vatandaşlık Ölçeği & $\begin{array}{c}\text { Varyansı Açılklama } \\
\text { Yüzdesi }\end{array}$ & $\begin{array}{c}\text { Cronbach-Alpha } \\
\text { (CA) }\end{array}$ & Cevap Ortalamasi \\
\hline Vicdanlılık & $\% 20.06$ & 0.910 & 4.32 \\
\hline Özgecilik & $\% 16.59$ & 0.908 & 4.22 \\
\hline Nezaket & $\% 12.30$ & 0.905 & 4.30 \\
\hline Centilmenlik & $\% 10.89$ & 0.902 & 2.58 \\
\hline Sivil Erdem & $\% 9.21$ & 0.899 & 4.03 \\
\hline \multicolumn{4}{|c|}{$\mathrm{KMO}=0.926 ;$ Bartlett $\chi 2=6538,51 \quad$ ve $\mathrm{p}=0.000 ;$ Varyans Aç1klama Yüzde: $\% 69.05$} \\
\hline Bilgi Paylaşımı Ölçeği & $\begin{array}{c}\text { Varyansı Açıklama } \\
\text { Yüzdesi }\end{array}$ & $\begin{array}{c}\text { Cronbach-Alpha } \\
\text { (CA) }\end{array}$ & Cevap Ortalaması \\
\hline Açık Bilgi & $\% 36.88$ & 0.916 & 3.50 \\
\hline Örtülü Bilgi & $\% 34.67$ & 0.914 & 3.43 \\
\hline
\end{tabular}

Faktör yapısında, liderlik tarzları için 2 faktör, örgütsel vatandaşlık davranışı için 5 faktör ve bilgi paylaşımı için 2 faktör öz değerleri 1'den fazla olacak şekilde tespit edilmiştir. Liderlik tarzları ölçeği Kaiser-Meyer-Olkin (KMO) örneklem yeterliliği, iyi bir seviyeyi belirten 0.70 oranının üzerinde 0.932 , örgütsel vatandaşlık davranışı ölçeği 0.926 ve bilgi paylaşımı ölçeği 0.920 olacak şekilde tespit edilmiştir. Analize tabi tutulacak olan değişkenlerin tutarlılıklarının ölçülmesinde kullanılan Bartlett küresellik testinin neticesi liderlik tarzları ölçeği açısından istatistiksel anlamlı $(\chi 2=6732.98$ ve $p=0.000)$, örgütsel vatandaşlık davranışı ölçeği açısından $(\chi 2=6538,51$ ve $p=0.001)$ ve bilgi paylaşımı ölçeği açısından $(\chi 2=7251.27$ ve $p=0.000) \quad$ olacak şekilde belirlenmiştir. Anti-imaj korelasyon matrisinden elde edilen sonuçlara göre, kavramların çapraz ilişki katsayıları kritik seviye olarak kabul edilen 0.5'in üzerinde liderlik tarzları ölçeği açısından (0.64-0.90) arasında, örgütsel vatandaşlık davranışı ölçeği açısından (0.67-0.93) arasında ve bilgi paylaşımı ölçeği açısından (0.71-0.92) arasında tespit edilmiştir. Her üç ölçek bakımından extraction (çıkarım) sütununda 0.20 oranının altında soru bulunmamaktadır, buna bağlı olarak da soru çıkarımına başvurulmamıştır.

Doğrulayıcı faktör analizi (DFA), verinin temelindeki yapıyı inceleyen açılayıcı faktör analizinin (AFA) uzantısıdır. DFA'nın esas hedefi, önceden tanımlanmış olan bir faktör yönteminin gözlenen veri setiyle uyuşma kabiliyetini yapı geçerliliğini tespit etmektir. DFA'dan, genel olarak geçerlilik analizlerinde ve ölçek geliştirmede yararlanılmaktadır. Ayrıca DFA, önceden tespit edilmiş bir yapının doğrulanmasını amaç edinmektedir (Johnson ve Wichern, 2014).

DFA verilerinin uygunluğunun tespiti amacıyla Tablo 2'de model için uyum istatistiklerinin kriter ve sonuçları gösterilmiştir.

Tablo 2: DFA Modeli Uyum İndeksleri

\begin{tabular}{lllll}
\hline $\begin{array}{l}\text { Ölçüm } \\
\text { (Uyum İstatistiği) }\end{array}$ & İyi Uyum & Kabul Edilebilir Uyum & $\begin{array}{l}\text { Araştırma } \\
\text { Modeli Değeri }\end{array}$ & Uyum Durumu \\
\hline $\begin{array}{lllll}\text { Genel Model Uyumu } \\
\mathbf{X}^{2} \text { sd }\end{array}$ & $\leq_{3}$ & $\leq_{4-5}$ & 2.16 & İyi uyum \\
\hline Karşılaştırmalı Uyum İstatistikleri & & & \\
NFI & $\geq_{0.95}$ & $0.94-0.90$ & 0.932 & Kabul edilebilir \\
TLI (NNFI) & $\geq_{0.95}$ & $0.94-0.90$ & 0.979 & İyi uyum \\
IFI & $\geq_{0.95}$ & $0.94-0.90$ & 0.983 & İyi uyum \\
CFI & $\geq_{0.97}$ & $\geq_{0.95}$ & 0.963 & Kabul edilebilir \\
RMSEA & $\leq_{0.05}$ & $0.06-0.08$ & 0.035 & Iyyi uyum \\
\multicolumn{2}{l}{ Mutlak Uyum İndeksleri } & & & \\
\hline
\end{tabular}




\begin{tabular}{lcccc}
\hline GFI & $\geq_{0.90}$ & $0.89-0.85$ & 0.944 & İyi uyum \\
AGFI & $\geq_{0.90}$ & $0.89-0.85$ & 0.931 & İyi uyum \\
Artık Temelli Uyum İndeksi & & & \\
\hline RMR & $\mathbf{S}_{\mathbf{0 . 0 5}}$ & $\mathbf{0 . 0 6 - 0 . 0 8}$ & $\mathbf{0 . 0 2 4}$ & İyi uyum \\
\hline
\end{tabular}

Tablo 2 'de $X^{2} /$ sd $=2.16$ elde edilmiştir, $\leq_{3}$ şartını sağlaması nedeniyle "iyi uyum" kararı kabul edilmiştir. NFI=0.932 ile 0.94-0.90 aralığına düşmektedir, "kabul edilir uyum" sağlanmıştır, TLI (NNFI)=0.979 ile $\geq 0.95$

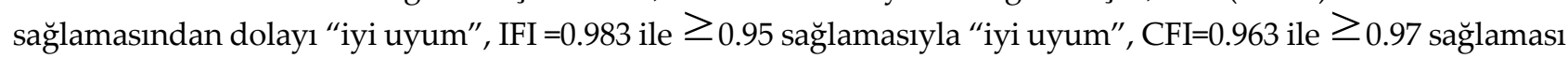
nedeniyle "kabul edilebilir uyum", RMSEA=0.035 ile $\leq_{0.05}$ sağlamasıyla "iyi uyum", GFI=0.944 ile $\geq_{0.90}$ sağlamasından dolayı "iyi uyum", AGFI=0.931 ile $\geq_{0.90}$ sağladığı için "iyi uyum", RMR=0.024 ile $\leq 0.05$ sağlamasıyla da "iyi uyum" sonuçları elde edilmiştir.

Yapısal eşitlik modeli (YEM); gözlenen değişkenler (observed variable) ve örtük değişkenler (latent variable) arasındaki nedensel bağlantıların ve korelasyon ilgilerinin bir arada olduğu modellerin test edilmesi amacıyla kullanılan istatistiksel bir teknik olup bağımlılık ilişkilerinin tahmininde, varyans, kovaryans analizleri, çoklu regresyon ve faktör analizleri gibi analizlerin birleşmesi sonucu ortaya çıkan çok değişkenli bir metottur (Barrett, 2007). Doğrulayıcı faktör analizi yaklaşımlarında ölçüm modelinden yararlanılırken, yol analizi yaklaşımında yapısal modellerden faydalanılmaktadır. YEM nedensel bağlantıların yapısal denklemler yardımıyla belirtilmesine destek olmaktadır.

Tablo 3: YEM Tahminine Yönelik Uyum İndeksleri

\begin{tabular}{|c|c|c|c|c|}
\hline $\begin{array}{l}\text { Ölçüm } \\
\text { (Uyum İstatistiği) }\end{array}$ & İyi Uyum & Kabul Edilebilir Uyum & $\begin{array}{l}\text { Araştırma } \\
\text { Modeli Değeri }\end{array}$ & Uyum Durumu \\
\hline \multicolumn{5}{|c|}{ Genel Model Uyumu } \\
\hline$X^{2} / s d$ & $\leq_{3}$ & $\leq_{4-5}$ & 2.34 & İyi uyum \\
\hline \multicolumn{5}{|c|}{ Karşılaştırmalı Uyum İstatistikleri } \\
\hline NFI & $\geq_{0.95}$ & $0.94-0.90$ & 0.939 & Kabul edilebilir \\
\hline TLI (NNFI) & $\geq_{0.95}$ & $0.94-0.90$ & 0.960 & İyi uyum \\
\hline IFI & $\geq_{0.95}$ & $0.94-0.90$ & 0.973 & İyi uyum \\
\hline CFI & $\geq_{0.97}$ & $\geq_{0.95}$ & 0.965 & Kabul edilebilir \\
\hline RMSEA & $\leq_{0.05}$ & $0.06-0.08$ & 0.016 & İyi uyum \\
\hline \multicolumn{5}{|c|}{ Mutlak Uyum İndeksleri } \\
\hline GFI & $\geq_{0.90}$ & $0.89-0.85$ & 0.954 & İyi uyum \\
\hline AGFI & $\geq_{0.90}$ & 0.89-0.85 & 0.968 & İyi uyum \\
\hline \multicolumn{5}{|c|}{ Artık Temelli Uyum İndeksi } \\
\hline$\overline{\text { RMR }}$ & $\leq_{0.05}$ & $0.06-0.08$ & 0.012 & İyi uyum \\
\hline
\end{tabular}

Tablo 3 'de $X^{2}$ /sd =2.34 değeri elde edilmiştir, $\leq 3$ şartını sağlaması nedeniyle "iyi uyum" kararı benimsenmiştir. NFI=0.939 ile 0.94-0.90 şartını sağlamasından dolayı "kabul edilebilir uyum", TLI $(\mathrm{NNFI})=0.960$ ile $\geq 0.95$ sağlamasıyla "iyi uyum", IFI $=0.973$ ile $\geq 0.95$ sağlaması nedeniyle "iyi uyum", CFI $=0.965$ ile $\geq 0.97$ sağladığ 1 için "kabul edilebilir uyum", RMSEA=0.016 ile $\leq 0.05$ sağlamasından dolayı "iyi uyum", GFI=0.954 ile $\geq 0.90$ sağlamasıyla "iyi uyum", AGFI=0.968 ile $\geq 0.90$ sağladığ 1 için "iyi uyum", RMR=0.012 ile $\leq 0.05$ sağladığından "iyi uyum" sonuçları elde edilmiştir. YEM tahminlerinin uyum kriterleri yalnızca biri açısından kabul edilebilir sonucunu vermiş, başka kriterler iyi uyumun sağlandığını, modelin yorum yapmaya uygunluk gösterdiğini ortaya çıkarmıştır. YEM analizi sonucunda elde edilen tahmin değerleri Tablo 4 'de verilmiştir. 
Tablo 4: YEM Tahmin Sonuçları

\begin{tabular}{lllllll}
\hline Yapısal ilişki & Yön & $\begin{array}{l}\text { Tahmin } \\
\text { edilen } \\
\text { katsay }\end{array}$ & St. Hata & t istatistiği & $\mathbf{p}$ & Sonuç \\
\hline $\mathbf{L T} \rightarrow \mathbf{B P}$ & + & 0.541 & 0.075 & 7.213 & $0.001^{*}$ & Anlamlı İlişki \\
$\mathbf{L T} \rightarrow$ ÖV & + & 0.130 & 0.019 & 6.842 & $0.003^{*}$ & Anlamlı İliski \\
& & & & & & \\
$\mathbf{B P} \rightarrow$ ÖV & + & 0.332 & 0.052 & 6.384 & $0.000^{*}$ & Anlamlı İlişki \\
\hline
\end{tabular}

*0.05 için anlamlı değişken

Bilgi paylaşımının aracı değişken olabilmesi için bazı koşulların sağlanması gerekmektedir. İlk olarak, bilgi paylaşımı olmadan, liderlik tarzı ile örgütsel vatandaşlık davranışları arasında anlamlı bir ilginin olması gerekmektedir. Eğer bu sağlanmaz ise, aracı etkinin tanımlanmasının anlamı yoktur. Bu nedenle, ilk aşamada liderlik tarzı ve örgütsel vatandaşlık davranışı için YEM uygulanmıştır. Liderlik tarzının örgütsel vatandaşlık davranışını 0.148 br. arttırıcı olduğu ve bu sonucun istatistik anlamlı olduğu belirlenmiştir. Bu sonuç, aracılık etkisinin ele alınması için ilk aşamanın sağlanması anlamına gelmektedir. İkinci aşamada, Şekil 3’de tanımlanan ve aracılık etkisini de kapsayan YEM'in analizi gerçekleştirilmiştir. Eğer bilgi paylaşımının aracı rolü varsa, liderlik tarzının katsayısının bu modelde düşmesi ama anlamlı olması beklenmektedir. Tablo 4'te belirtildiği gibi, liderlik tarzı örgütsel vatandaşlık davranışını 0.130 br. arttırıcı ve anlamlı etkiye sahiptir. Katsayı değeri düşmüştür.

Diğer yandan, bir aracılık etkisinden sözetmek için, aynı zamanda liderlik tarzının da bilgi paylaşımı üzerinde anlamlı etkili olması gerekmektedir. Tablo 4'e göre, liderlik tarzı bilgi paylaşımını 0.541 br. arttırıcı ve anlamlı etkiye sahiptir. Aynı zamanda bilgi paylaşımın da örgütsel vatandaşlık üzerinde 0.332 br. anlamlı etkili olduğu belirlenmiştir. Tüm bu aşamalar, bilgi paylaşımının aracı değişken olması konusunda olumlu bir durumu belirtmektedir. AMOS programında dolaylı (indirect) etkiler boostrap metodolojisi ile otomatik verilmektedir. Standardize edilmiş dolaylı etki seçilir ve etki katsayılarının anlamlılığına bakılır. Eğer, $p$ değeri 0.05 değerinden az ise, bilgi paylaşımının liderlik tarzının örgütsel vatandaşlık davranışına aracılık ettiği sonucuna ulaşılacaktır.

Bilgi paylaşımının liderlik tarzı ile örgütsel vatandaşlık davranışı arasındaki aracılık görevinin anlamlılığının test edilebilmesi amacıyla bootstrap analizi uygulanmıştır. Analize yönelik olarak doğrudan ve dolaylı yollar hususundaki katsayı ve güven aralıkları Tablo 5'te belirtilmiştir.

Tablo 5: Modele Yönelik Standardize Bootstrap Analizi

\begin{tabular}{|c|c|c|}
\hline Model Yolu & Katsayı & $\begin{array}{l}\text { \%95 Güven Aralığ1 } \\
\text { Alt-Üst }\end{array}$ \\
\hline \multicolumn{3}{|l|}{ Doğrudan etki } \\
\hline $\mathrm{LT} \rightarrow \mathrm{BP}$ & 0.281 & $0.268-0.294$ \\
\hline $\mathrm{LT} \rightarrow \mathrm{ÖV}$ & 0.172 & $0.154-0.182$ \\
\hline $\mathrm{BP} \rightarrow \mathrm{O} \mathrm{V}$ & 0.164 & $0.158-0.171$ \\
\hline \multicolumn{3}{|l|}{ Dolaylı etki } \\
\hline $\mathrm{LT} \rightarrow \mathrm{BP} \rightarrow \mathrm{ÖV}$ & 0.051 & $0.028-0.067$ \\
\hline
\end{tabular}

Sonuçlara bakıldığında, bootstrap standardize edilmiş değer aralıklarının sıfır olmadığı ve anlamlı olduğu görülmektedir (bootstrap katsayısı=0.051, GA\%95 =0.028-0.067). Söz konusu durum bilgi paylaşımının liderlik tarzıyla örgütsel vatandaşlık davranışları arasındaki aracılık rolünün bulunduğunu açıklamaktadır. Modelin ana hipotezini oluşturan $\mathrm{H}_{1}, \mathrm{H}_{2}, \mathrm{H}_{3}$ ve $\mathrm{H}_{4}$ doğrulanmıştır.

\section{SONUÇ VE TARTIŞMA}

İşletme içerisinde çalışanların davranış ve tutumları üzerinde "Liderlik" olgusunun etkisi bulunmaktadır. Liderlerin çalışanlarına yönelik geliştirdiği davranış ve tutumlar, hem çalışanların bağlı bulundukları işletmeye hem de kendi işlerine karşı olan duygu ve düşünceleri üzerinde etkili olmaktadır. Liderlik tarzının etki ettiği bu davranış ve tutumlar arasında bilgi paylaşımı ve örgütsel vatandaşlık davranışı bulunmaktadır. 


\section{P. Tahari - N. T. İrge 13/4 (2021) 3652-3667}

$\mathrm{Bu}$ uygulamanın amacl, liderlik tarzlarının, örgütsel vatandaşlık davranışı üzerindeki etkisinde bilgi paylaşımının aracılık rolünü belirlemektir. YEM analizi sonucunda, liderlik tarzı bilgi paylaşımını $0.541 \mathrm{br}$. arttırıcı ve anlamlı etkiye sahip, aynı zamanda bilgi paylaşımın da örgütsel vatandaşlık üzerinde $0.332 \mathrm{br}$. anlamlı etkili olduğu belirlenmiştir. Bilgi paylaşımının liderlik tarzı ile örgütsel vatandaşlık davranışları arasında yer alan aracılık rolünün anlamlılı̆̆ının test edilebilmesi amacıyla bootstrap analizinden yararlanılmıştır. Bootstrap standardize edilmiş değer aralıklarının sıfır içermediği ve anlamlı olduğu görülmüştür. Bu durum, bilgi paylaşımının liderlik tarzı ile örgütsel vatandaşlık davranışı ilişkisinde aracılık rolünün olduğunu göstermiştir.

Literatür incelendiğinde; Oğuz (2011) çalışmasında, ilköğretim okullarında görev yapan öğretmelerin sergiledikleri örgütsel vatandaşlık davranışı ile yöneticilerinin gösterdikleri liderlik tarzı arasında pozitif yönlü anlamlı ilişki bulmuşlardır. Harwiki (2013) çalışmasında, bankacılık sektörü çalışanları için yaptığı araştırmada etik liderlik ile örgütsel vatandaşlık davranışları arasında pozitif yönde anlamlı ilişki belirlemiştir. Zehir vd. (2013)'de ofis çalışanlarına yönelik araştırmasında liderlik ile örgütsel vatandaşlık davranışları arasında pozitif yönde anlamlı ilişki belirlemiştir. Bambale (2014) çalışmasında, hizmet sektörü çalışanları için yaptıkları araştırmada örgütsel vatandaşlık ve dönüşümcü liderlik arasında pozitif yönlü ilişki belirlemiştir. Alkan (2017) çalışmasında, bankacılık sektörü çalışanlarına yönelik etik liderlik ile örgütsel vatandaşlık davranışları arasında pozitif yönde anlamlı ilişki belirlemiştir. Bu çalışmanın sonuçları, Palomino ve Cañas (2014) ve Ülkü (2014) ile paraleldir. Aynı şekilde, Ay ve Büyükyılmaz (2017) çalışmasında iki devlet hastanesi çalışanları için aynı sonuçlara ulaşmıştır. Khalili (2017) çalışmasında, elli şirketin çalışınlarına uyguladığı anket sonucunda dönüşümcü liderlik ve örgütsel vatandaşlık davranışı arasında anlamlı ilişki bulmuştur.

Daha sonrasında; Kuruşçu ve Aydoğan (2018)'de yaptığı araştırmasından elde edilen veriler neticesinde, dönüşümcü liderlikle genel örgütsel vatandaşlık davranışı ve bütün boyutları arasında anlamlı ve pozitif yönde bir ilişkinin var olduğu belirlenmiş, etkileşimci liderliğin koşullu ödüllendirme davranışıyla örgütsel vatandaşlık davranışının sivil erdem hariç genel örgütsel vatandaşlık davranışı ve dört boyutu arasında anlamlı ve pozitif yönde bir bağlantı saptanmış, etkileşimci liderliğin koşullu ödüllendirme davranışıyla örgütsel vatandaşlık davranışının sivil erdem boyutu arasında anlamlı bir bağlantı olmadığını belirlemiştir. Podsakoff vd. (1990), Özcan vd. (2012) ve Morçin ve Morçin (2013) bulgularına benzer şekilde de anlamlı ve pozitif yönlü bir ilişki olduğu belirlenmiştir. Bu sonuçlar, çalışmadan elde edilen analiz sonuçlarını destekler niteliktedir.

Literatürde; Srivastava vd. (2006) yaptığı çalışmada, bilgi paylaşımı noktasında güçlendirici liderlik yaklaşımının önemli etkisinin olduğunu ortaya koymaktadır. Gagne (2009), büro çalışanları için liderlik tarzlarının bilgi paylamı üzerinde anlamlı etkisi olduğunu belirlemiştir. Karaaslan vd. (2009) yaptığ1 araştırmasında, örgütsel vatandaşlık davranışının boyutlarıyla bilgi paylaşımı davranışı değişkenlerinin arasında pozitif bir ilişki tespit etmiştir. Boyutlar bakımından söz konusu bağlantının bireysel gelişim ile sivil erdem boyutları arasında orta düzeyde; bireysel girişkenlik, centilmenlik, örgütsel itaat ve yardım etme boyutları arasında zayıf oranda bulunduğu verisine ulaşılmıştır. Han vd., (2016) çalışmasında bankacılık sektöründe dönüşümcü liderlik ile bilgi paylaşımı arasında pozitif yönlü ilişki belirlemiştir. Masa'deh vd. (2016) çalışmasında, liderlik tarzlarının performansa etkisinde bilgi paylaşımının aracı rolünü belirlemişlerdir. Bavik (2017) lojistik sektörü çalışanları araştırmasında, etik liderlik ile bilgi paylaşımı arasındaki pozitif yönlü ilişki belirlemiştir. Zeb vd., (2019) çalışmalarında farklı şirket çalışanlarına yaptıkları anket sonucunda otantik liderlik ile bilgi paylaşımı arasında negative yönlü ilişki belirlemiştir. Mertel vd. (2020) çalışanlar üzerinde yaptığı araştırmasında dönüşümcü liderlik ile bilgi paylaşımı arasında orta seviyede pozitif yönlü bir ilgi olduğunu saptamıştır. Yapılan araştırma makalelerinin analiz sonuçları araştırma sonuçlarını desteklemektedir.

Çalışmada hedef kitle olarak yükseköğretim kurumu seçilmesinin nedeni, mezun olduktan sonra yeni çalışan nesilleri oluşturacak olan öğrencilerin algılarının, eğitim aldıkları üniversitelerin ortamından ve akademisyenlerin davranışlarından etkilendiği gerçeğidir. Üniversiteler kurum olarak bilgiye dayalı örgütlerdir. Eğitim sektörünü iş olarak seçen insanların bilgiye ve bilgi paylaşımına önem veren karakterlere sahip olmaları beklenmektedir. İnsanların davranışları örgütlerden etkilenmektedir. Dolayısıyla, liderlik tarzının örgütsel vatandaşlık davranışı ve bilgi paylaşımı üzerindeki etkisinin önemi, eğitim sektörünün kendi iç dinamikleri yoluyla değil, mezun olan öğrencilerin algıladıkları biçimde, çalıştıkları ve ilişkide oldukları sektörlere yayılması ile yer bulacaktır. Üniversitelerde liderlik tarzlarının akademik personelin örgütsel 


\section{P. Tahari - N. T. İrge 13/4 (2021) 3652-3667}

vatandaşlık davranışlarına etkisi nedir? ve bu etkide bilgi paylaşımının rolü nedir? sorularının cevabı bu nedenle çok önemlidir. Benzer bir araştırma eğitim sektöründe bulunmadığı için, çalışmanın literatüre katkı sağlayacağı düşünülmektedir.

Çalışmanın önerileri olarak; Vakıf üniversitelerinde çalışan akademisyenlerin ve liderlerin örgütsel vatandaşlık davranışlarının nedenleri araştırılarak, devlet üniversitelerinde çalışan akademisyenlerden elde edilen sonuçlarla karşılaştırılabilir. Göreve yeni başlamış ve genç akademisyenler ile liderlere örgütsel vatandaşlık davranışlarını sergileme durumlarının gelecekte değişmemesi için davranışlarına yönelik manevi ödüller verilebilir. Akademisyenlerin ve liderlerin örgütsel vatandaşlık davranışı sergilemeleri için akademisyenler ve liderler arası etkileşimi artırıcı çalışmalar yapılabilir. Vakıf üniversitelerde ve devlet üniversitelerinde akademisyenlerin ve yöneticilerin bilgi paylaşımını destekleyecek bir kültür teşvik edilmelidir. Ayrıca, ilerideki çalışmalar açısından, Türkiye geneli için farklı illerde faaliyet gösteren üniversitelerde farklı ölçekler ve ilişkiler tanımlayarak çalışmanın genişletilmesi önerilmektedir.

\section{KAYNAKÇA}

Alkan, D., ve Arıkboğa, F. Ş. (2017). Etik Liderlik ve Örgütsel Vatandaşlık Davranışı İlişkisinde Örgütsel Özdeşleşmenin Aracllık Etkisi ve Bir Uygulama, Yönetim ve Ekonomi Dergisi, 24(2), 349-369 .

Altıntaş, E. (2019). Dönüşümcü liderlik ve örgütsel vatandaşlık davranışı arasındaki ilişkide kişi-örgüt uyumunun rolü, Yayınlanmamış Yüksek Lisans Tezi, Hacettepe Üniversitesi Sosyal Bilimler Enstitüsü, Ankara.

Aydın, Y. (2015). Liderlik tarzları ile örgütsel vatandaşlı davranışı arasındaki ilişkide örgüt kültürünün rolü: bursa serbest bölgesinde faaliyet gösteren firmalar üzerine bir araştırma. Yayınlanmamış Doktora Tezi, Çukurova Üniversitesi Sosyal Bilimler Enstitüsü, Adana.

Aydoğdu, S. (2013). An empirical study of the relationship between leadership styles and organizational commitment: the mediating role of empowerment. Unpublish Doctoral Thesis, Okan University Institute of Social Sciences, Istanbul.

Bambale, A. J. (2014). Relationship between servant leadership and organizational citizenship behaviors: review of literature and future research directions. Journal of Marketing and Management, 5(1), 1-16.

Bass, B. M. and Avolio, B. J. (1993). Transformational leadership: a response to critiques. In (Ed. M. M. Chemers and R. Ayman), Leadership Theory And Research: Perspectives And Directions, (pp.49-80). London: Academic Press.

Bass, B. M. (1985). Leadership and Performance Beyond Expectation. New York: The Free Press.

Bavik, Y. L., Tang, P. M., Shao, R. and Lam, L. M. (2018). Ethical leadership and employee knowledge sharing: Exploring dual-mediation paths. The Leadership Quarterly, 29(2), 322-332.

Barrett, P. (2007). Structural equation modelling: Adjudging model fit. Personality And Individual Differences, 42(5), 815-824.

Bello, S. M. (2012). Impact of ethical leadership on employee job performance. International Journal of Business and Social Science, 3(11), 228-236.

Bhargawi, S., and Yaseen, A. (2016). Leardership styles and organizational performance. Strategic Management Quarterly, 4(1), 87-117.

Borman, C. W., Penner, L. A., Allen, T. D. and Motowidlo, S. T. (2001). Personality Predictors of Citizenship Performance, International Journal of Selection and Assessment, 9(1/2), 52-66.

Büyükyılmaz, O. ve Alper Ay, F. (2017). Etik Liderliğin Örgütsel Vatandaşlik Davranişina Etkisinde Örgütsel Adaletin Aracilik Rolü, Hitit Üniversitesi Sosyal Bilimler Enstitüsü Dergisi, 10(1), 209-233.

Camelo-Ordaz, C., García-Cruz, J., Sousa-Ginel, E. and Valle-Cabrera, R. (2011). The influence of human resource management on knowledge sharing and innovation in spain: the mediating role of affective commitment. International Journal of Human Resource Management, 22(7), 1442-1463.

Cohen, D. (1998). Toward a knowledge context:report on the first annual U. C. Berkeley forum on knowledge and firm. California Management Review, 40(3), 22-39. 


\section{P. Tahari - N. T. İrge 13/4 (2021) 3652-3667}

Connelly, C., Zweig, D., Webster, J., and Trougakos, J. (2012). Knowledge hiding in organizations. Journal of Organizational Behavior, 33(1), 64-88.

Cooper, D. J. (2003). Leadership for follower commitment. Burlington: Routledge Pbc.

Çetinkaya, M. (2014). Örgütsel adalet algısının örgütsel vatandaşlık davranışı üzerindeki etkisi ve örgütsel özdeşleşmenin aracılık rolü: yapısal eşitlik modeli çalışması. Yönetim Bilimleri Dergisi, 23(12), 237-278.

Demirel, Y., Seçkin, Z. ve Özçınar, M. F. (2011). Örgütsel iletişim ile örgütsel vatandaşlık davranışı arasındaki ilişki üzerine bir araştırma. Çukurova Üniversitesi Sosyal Bilimler Enstitüsü Dergisi, 20(2), 33-47.

Dyer, J. H. and Singh, H. (1998). The relational view: cooperative strategy and sources of interorganizational competitive advantage. Academy of Management Review, 23(1), 660-679.

Gagné, M. (2009). A model of knowledge-sharing motivation. Human Resource Management, 48(4), 571-589.

George, M. J., and Jones, G. R. (2008). Understanding and managing organizational behavior. New Jersey: Prentice Hall Pbc.

Han, S. H., Seo, G., Yoon, S. W. and Yoon, D. Y. (2016). Transformational leadership and knowledge sharing: Mediating roles of employee's empowerment, commitment, and citizenship behaviors. Journal of Workplace Learning, 28(3), 130-149.

Harwiki, W. (2013). The influence of servant leadership on organization culture, organizational commitment, organizational citizenship behavior and employees. performance (study of outstanding cooperatives in east java province, indonesia). Journal of Economics and Behavioral Studies, 5(12), 876-885.

Heisig, P., Suraj, O. S., Kianto, A., Kemboi, C., Arrau, G. P., and Easa, N. F. (2016). Knowledge management and business performance: global experts' views on future research needs, Journal of Knowledge Management, 20(6), 1169-1198.

Hodgetts, R. M. (1999). Management theory, process and practice. (Çeviri: C. Çetin ve E. C. Mutlu). İstanbul: Beta Yayıncilik.

Hsu, I. C., and Sabherwal, R. (2012). Relationship between intellectual capital and knowledge management: An empirical investigation, Decision Sciences, 43, 489-524.

Johnson, R. A., and Wichern, D. W. (2014). Applied multivariate statistical analysis, New Jersey: Prentice-Hall.

John, S., and Chattopadhyay, P. (2015). Factors impacting leadership effectiveness: a literature review. Arabian Journal of Business and Management Review, 5(6), 1-5.

Jyoti, J., and Bhau, S. (2015). Impact of transformational leadership on job performance: mediating role of leader-member exchange and relational identification. SAGE Open, 5(4), 1-13.

Kağıtçıbaşı, Ç., ve Cemalcılar, Z. (2017). Dünden bugüne insan ve insanlar (Sosyal Psikolojiye Giriş), İstanbul: Evrim Yayınevi.

Karaaslan, A., Ergun Özler, D. ve Kulaklığlu, A. S. (2009). Örgütsel vatandaşlık davranışı ve bilgi paylaşımı arasındaki ilişkiye yönelik bir araştırma. Afyon Kocatepe Üniversitesi İ.I.B.F. Dergisi, 11(2), 135-160.

Keskin H., Ayar Şentürk H., ve Beydoğan A. (2018). Yenilikçilik kalitesi perspektifinden bilgi paylaşımı, entelektüel sermaye ve performans ilişkisi. BMIJ, 6(3), 71-94.

Kianto, A., Saenz, J., and Aramburu, N. (2017). Knowldege based human resource management practices, intellectual capital and innovation. Journal of Business Research, 81(1), 11-20.

Kuruşçu, M. ve Aydoğan, S. (2018). Liderlik tarzı ile örgütsel vatandaşlık davranışı ilişkisi: bir özel eğitim kurumunda uygulama. Savunma Bilimleri Dergisi, 17(2), 167-206.

Lee, W. J., Jun, J., and Lee, T. (2016). Sharing behavior and its relationship with core competencies of a company: a grounded theory approach. Indian Journal of Science and Technology, 9(5), 1-9.

Lee, M. K. O., Cheung, C. M. K., Lim, K. H., and Sia, C. L. (2006). Understanding customer knowledge sharing in web-based discussion boards, Internet Research,16(3), 289-303.

Longe, O. J. (2014). Leadership style paradigm shift and organisational performance: A case of the Nigerian cement industry. African Research Review, 8(4), 68-83.

Loebbecke, C., Van Fenema, P. C., and Powell, P. (2016). Managing inter-organizational knowledge sharing. The Journal of Strategic Information Systems, 25 (1), 4-14. 


\section{P. Tahari - N. T. İrge 13/4 (2021) 3652-3667}

Masa'deh, R., Obeidat, B. Y. and Tarhini, A. (2016). A Jordanian empirical study of the associations among transformational leadership, transactional leadership, knowledge sharing, job performance, and firm performance: A structural equation modelling approach. Journal of Management Development, 35(5), 681-705.

Mertel, K., Bozkurt, S. ve Demirhan, A. (2020). Dönüşümcü liderlik tarzının bilgi paylaşımına etkisinde destekleyici örgüt ikliminin aracı rolünü yönelik bir araştırma. Social Sciences, 15(6), 3073-3087.

Mo, S. and Shi, J. (2017). Linking ethical leadership to employees' organizational citizenship behavior: testing the multilevel mediation role of organizational concern, Journal of Business Ethics, 141(1),151-162.

Morçin, S. E. ve Morçin, İ. (2013). Etkileşimci Liderliğin Örgütsel Vatandaşlık Davranışına Etkisi: Adana'daki Seyahat Acenteleri Örneği, Süleymen Demirel Üniversitesi Vizyoner Dergisi, 4(9), 70-80.

Naktiyok, S. (2019). Otel Çalışanlarının Örgütsel Vatandaşlık Davranışlarının İş Performansı Üzerine Etkisi: Sivas İlinde Bir Uygulama. Journal of Tourism and Gastronomy Studies, 7(2), 1057-1076.

Nonaka, İ., and Takeuchi, H. (1995). The knowledge-creating company: how japanese companies create the dynamics of innovation, New York: Oxford University Press.

Oğuz, E. (2011). Öğretmenlerin örgütsel vatandaşlık davranışları ile yöneticilerin liderlik stilleri arasındaki ilişki. Kuram ve Uygulamada Ĕ̆itim Yönetimi, 17(3), 377-403.

Organ, D.W. (1988). Organizational Citizenship Behavior: The Good Soldier Syndrome, Lexington: Lexington Books.

Özcan, E. D., Vardarlıer, P., Karabay, M. E., Konakay, G. ve Çetin, C. (2012). Liderliğin örgütsel vatandaşlık davranışı ve işten ayrılma niyeti üzerindeki etkisinde güvenin rolü, Öneri Dergisi, 37(10), 1-13.

Öztekin, A., Delen, D., Zaim, H., Türkyılmaz, A., ve Zaim, S. (2015). The influence of knowledge management on financial and non-financial performance. Journal of Information E Knowledge Management, 14(02), 114.

Palomino, P. R., and Cañas, R. M. (2014). Ethical culture, ethical intent, and organizational citizenship behavior: the moderating and mediating role of person-organization fit. Journal of Business Ethics 120(1),95-108.

Podsakoff, P.M., MacKenzie, S.B., Moorman, R.H. and Fetter, R. (1990). Transformational leader behaviors and their effects on followers' trust in leader, satisfaction, and organizational citizenship behaviors. The Leadership Quarterly, 1(2), 107-142.

Podsakoff, P. M., Mackenzie, S. B., Paine, J. B. and Bachrach, D. G. (2000). Organizational citizenship behaviours: a critical review of the theoretical and empirical literature and suggestions for future research. Journal of Management, 26(1), 513-563.

Saleem, H. (2015). The impact of leadership styles on job satisfaction and mediating role of perceived organizational politics. Procedia-Social and Behavioral Sciences, 172(1), 563-569.

Sart G., Sezgin, F. H. ve Demir, N. (2018). Mobbingin mesleki tükenmişlik algısı üzerine etkileri:kadın akademisyenler örneği. Beykoz Akademi Dergisi, 6(1), 118-135.

Sart, G. (2020). Bireysel girişimcilik eğilimi ölçeğinin geliştirilmesi: geçerlik ve güvenirlik çalışması. International Journal of Applied Economic and Finance Studies, 1(5), 58-72.

Sezgin, F. H. ve Kinay, B. (2010). A dynamic factor model for evaluation of financial crises in turkey. Bulletin De la Societe des Sciences Medicales, No: 1/10, 109-117.

Sezgin, F. H. (2016). Bayesci faktör analizi ve maslach tükenmişlik envanteri uygulaması. International Conference on Scientific Cooperation for the Future in the Social Sciences (USAK) Bildiriler Kitab1, 1283-1296.

Shafique, I., Ahmad, B. and Kalyar, M. N. (2019). How ethical leadership influences creativity and organizational innovation: Examining the underlying mechanisms. European Journal of Innovation Management, 23(1),114-133.

Schutte, N., and Barkhuizen, N. (2015). Knowledge management and sharing in local government: a social 1dentity theory perspective. Electronic Journal of Knowledge Management, 13(2), 130-141.

Sougui, A. O., Bon, A. T., and Hassan, H. M. H. (2015). The impact of leadership styles on employees' performance in telecom engineering companies. Australian Journal of Basic and Applied Sciences, 8(4), 113. 


\section{P. Tahari - N. T. İrge 13/4 (2021) 3652-3667}

Sun, L.Y., Aryee, S. and Law, K.S. (2007). High performance human resource management practices, citizenship behavior, and organizational performance: a relational perspective. Academy of Management Journal, 50(3), 558-577.

Suppiah, V., and Sandhu, M. S. (2011). Organisational culture's influence on tacit knowledge-sharing behaviour. Journal Of Knowledge Management, 15(3), 462-477.

Srivastava, A., Bartol, K. M. and Locke, E. A. (2006). Empowering leadership in management teams: Effects on knowledge sharing, efficacy, and performance. Academy of Management Journal, 49(6), 1239-1251.

Tambe, S. and Shanker, D. M. (2014). A study of organizational citizenship behavior (OCB) and its dimensions: a literature review. International Research Journal of Business and Management, 1(1), 67-73.

Tanaka, K. (2013). Organizational citizenship behavior in contemporary workplaces in Japan. Japan Labor Review, 10(3), 5-18.

Uçar, İ. (2018). İşletmelerde çatışma yönetimi tarzları ile bilgi paylaşımı ilişkisi ve bir araştırma. Yayınlanmamış Yüksek Lisans Tezi, Marmara Üniversitesi Sosyal Bilimler Enstitüsü, İstanbul.

Ünüvar, T. G. (2006). An integrative model of job characteristics, job satisfaction, organizational commitment, and organizational citizenship behavior. Yayınlanmamış Yüksek Lisans Tezi, Ortadoğu Teknik Üniversitesi Sosyal Bilimler Enstitüsü, Ankara.

Van Wart, M. (2013). Lessons from leadership theory and the contemporary challenges of leaders. Public Administration Review, 73(1), 553-565.

Wang, S., and Noe, R. (2010). Knowledge sharing: a review and directions for future research. Human Resource Management Review, 20(1), 115-131.

Wang, G., Oh, I.-S., Courtright, S. H., and Colbert, A. E. (2011). Transformational leadership and performance across criteria and levels: a meta-analytic review of 25 years of research. Group $\mathcal{E}$ Organization Management, 36(2), 223-270.

Werner, E. E. (1993). Risk, resilience, and recovery: Perspectives from the Kauai longitudinal study. Development and Psychopathology, 5(4), 503-515.

Yazıcıŏ̆lu, Y. ve Erdoğan, S. (2004). SPSS Uygulamalı Bilimsel Araştırma Yöntemleri, Ankara: Detay Yayıncılık.

York-Barr, J., and Duke, K. (2004). What do we know about teacher leadership? findings from two decades of scholarship. Review of Educational Research, 74(3), 255-316.

Yorgancıŏ̆lu, T. G., Yeşilaydın, G. ve Karahan, A. (2019). Örgütsel bağlılık ve örgütsel vatandaşlık davranışının incelenmesi: sağlık çalışanları üzerine bir araştırma. Hacettepe Să̆lık İdaresi Degisi, 22(1), 157-180.

Yukl, G. (2010). Leadership in organizations (7th edition). New Jersey: Prentice Hall Pbc.

Yurtkoru, S. (2001). The role of leadership in the organizational change process, Yayınlanmamış Yüksek Lisans Tezi, Marmara Üniversitesi Sosyal Bilimler Enstitüsü, İstanbul.

Yüksek Öğretim Kurumu (YÖK), https://istatistik.yok.gov.tr/, (Erişim Tarihi:12.06.2021).

Zehir, C., Akyuz, B., Eren, M. S., ve Turhan, G. (2013).The indirect effects of servant leadership behavior on organizational citizenship behavior and job performance: organizational justice as a mediator. International Journal of Research in Business and Social Science, 2(3), 1-13.

Zel, U. (2011). Kişilik ve liderlik. Üçüncü Basım, Ankara: Nobel Yayıncılık. 